\title{
Three Structural Features of Functional Food Components and Herbal Medicine with Amyloid $\beta 42$ Anti-Aggregation Properties
}

\author{
Kazuma Murakami *(D) and Kazuhiro Irie *D \\ Division of Food Science and Biotechnology, Graduate School of Agriculture, Kyoto University, \\ Kyoto 606-8502, Japan \\ * Correspondence: alzkazu@kais.kyoto-u.ac.jp (K.M.); irie@kais.kyoto-u.ac.jp (K.I.); Tel.: +81-75-753-6282 (K.M.); \\ +81-75-753-6281 (K.I.)
}

Academic Editor: Gal Bitan

Received: 15 May 2019; Accepted: 4 June 2019; Published: 5 June 2019

\begin{abstract}
Aggregation of amyloid $\beta 42$ (A $\beta 42)$ is one of the hallmarks of Alzheimer's disease (AD). There are numerous naturally occurring products that suppress the aggregation of $A \beta 42$, but the underlying mechanisms remain to be elucidated. Based on NMR and MS spectroscopic analysis, we propose three structural characteristics found in natural products required for the suppressive activity against $A \beta 42$ aggregation (i.e., oligomerization by targeting specific amino acid residues on this protein). These characteristics include (1) catechol-type flavonoids that can form Michael adducts with the side chains of Lys 16 and 28 in monomeric $A \beta 42$ through flavonoid autoxidation; (2) non-catechol-type flavonoids with planarity due to $\alpha, \beta$-unsaturated carbonyl groups that can interact with the intermolecular $\beta$-sheet region in $A \beta 42$ aggregates, especially aromatic rings such as those of Phe19 and 20; and (3) carboxy acid derivatives with triterpenoid or anthraquinoid that can generate a salt bridge with basic amino acid residues such as Lys16 and 28 in the A $\beta 42$ dimer or trimer. Here, we summarize the recent body of knowledge concerning amyloidogenic inhibitors, particularly in functional food components and Kampo medicine, and discuss their application in the treatment and prevention of $\mathrm{AD}$.
\end{abstract}

Keywords: amyloid $\beta$; Alzheimer's disease; aggregation; oligomer; neurotoxicity; natural product; flavonoid; triterpenoid; NMR; mass spectrometry

\section{Introduction}

Alzheimer's disease (AD) is an irreversible neurodegenerative disorder. The two pathological hallmarks of $\mathrm{AD}$ are the accumulation of amyloid $\beta(\mathrm{A} \beta)$ protein deposits in extracellular senile plaques and the accumulation of tau protein induced from hyperphosphorylation mainly by glycogen synthase kinase $3 \beta$ (GSK-3 $\beta$ ) in intracellular neurofibrillary tangles [1]. The amyloid cascade hypothesis, originally proposed by Hardy and Higgins [2], is widely accepted. This hypothesis holds that the deposition of $A \beta$ is the earliest event in $A D$ progression, and that $A \beta$ aggregation can trigger the tau-related pathologies of $\mathrm{AD}$. The aggregation of $A \beta$ is therefore a potential target for the diagnosis and treatment of $\mathrm{AD}$. $\mathrm{A} \beta$ itself is considered a physiological by-product of cellular metabolism because it can be detected as a circulating protein in the cerebrospinal fluid and blood of healthy humans [3]; the physiological function of $A \beta$ is summarized in a recent review by Panza et al. [4]. The 40-mer and 42-mer $A \beta(A \beta 40, A \beta 42)$ proteins are produced from $A \beta$ precursor protein (APP) $[5,6]$. The ability of $A \beta 42$ to aggregate (i.e., oligomerize and fibrillize), and therefore to show neurotoxicity, is higher than that of $A \beta 40$. Metastable oligomers of $A \beta 42$ cause memory loss and synaptotoxicity, whereas the contribution of end-stage matured fibrils to the etiology of $\mathrm{AD}$ is smaller $[7,8]$. $\mathrm{A} \beta$ oligomers can exist 
in the equilibrium state, resulting in a heterogeneous mixture of various forms of intermediates by multiple pathways. Most A $\beta 42$ oligomers are higher-order oligomers (24-700-mer) such as protofibrils (PFs) [9,10], A $\beta$-derived diffusible ligands [11], and amylospheroid [12], which are potently neurotoxic. Because there remain unanswered questions regarding which types of oligomers contribute the most to the pathogenesis of $\mathrm{AD}$, developing multi-target inhibitors for these higher-order oligomers is imperative for making meaningful progress toward AD therapy. Furthermore, given the negative results in the recent clinical trials using $A \beta$-targeted drugs, some researchers are skeptic about the $\mathrm{A} \beta$ cascade. Meanwhile, functional food components and Kampo medicine with pleiotropic ability have gained attention. Especially, Kampo medicine has been long used for the symptomatic treatment of many diseases. Epidemiological studies have suggested that dietary habits could regulate the occurrence rate of $\mathrm{AD}$. Several edible natural products have been characterized with effects such as anti-A $\beta$ aggregation as well as anti-oxidative stress and anti-inflammation [13]. There have been a number of comprehensive papers including an encyclopedia and reviews on anti-A $\beta$ aggregative polyphenols and flavonoids (e.g., chrysin, rutin, fisetin, resveratrol, and apigenin) [14-23]. However, the mechanisms underlying the anti-aggregative activity of most of these natural products remain to be elucidated.

The current review describes the polymerization mechanisms of $A \beta 42$ and the strategy by which chemical agents such as flavonoids and terpenoids can control the aggregation or disaggregation of A $\beta 42$. We focus on three structural features described under the following subsections: Section 3.1. catechol moiety, Section 3.2. planarity, and Section 3.3 carboxy group required for the activity of such chemical agents based on analysis using nuclear magnetic resonance (NMR) spectroscopy and mass spectrometry (MS). We also discuss the in vivo metabolism of these inhibitors, including blood-brain barrier permeability and brain-gut interaction, toward developing anti-AD drugs.

\section{Nucleation-Dependent Polymerization Mechanism of A $\beta 42$}

\subsection{Overview}

Naiki and coworkers proposed a nucleation-dependent polymerization mechanism that includes nucleation and elongation phases. This mechanism is currently accepted as an aggregation mechanism for $A \beta 42$ in vitro [24]. During the nucleation phase, the monomeric $A \beta 42$ gradually forms low-molecular-weight oligomers (i.e., "nuclei") [25] before the elongation phase, during which each nucleus acts as a template and associates with monomers to initiate polymerization (Figure 1a). The elongation phase contains two pathways: on-pathway to move into fibrillization and off-pathway not to move into it. The higher-order oligomers mentioned above can exist between nuclei and amyloid fibril, though it remains controversial to which pathway each of the higher-order oligomers belong. Thereafter, depending on various factors including temperature, endogenous substances such as metal [26,27], lipid membrane [28], and apolipoprotein E [29], the amyloid products are roughly divided into two forms, namely well-defined cross- $\beta$-sheet amyloid fibrils and metastable high-order oligomers. In contrast to the neurotoxic high-order oligomers described above, fibrils as an end product are occasionally assumed to serve as an amyloid reservoir for confining toxic $A \beta$ species [30]. Owing to the lower toxicity of fibrils, finding compounds that can convert oligomers into relatively inert fibrils, such as orcein-related compound $\mathrm{O} 4$, may be helpful for treating $\mathrm{AD}$ [31]. 
(a)

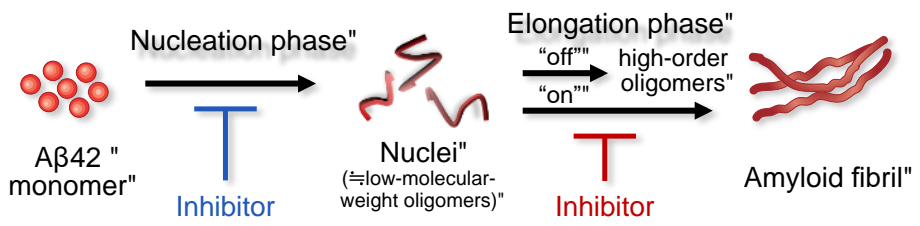

Delayed nucleation phase

Suppressed elongation phase
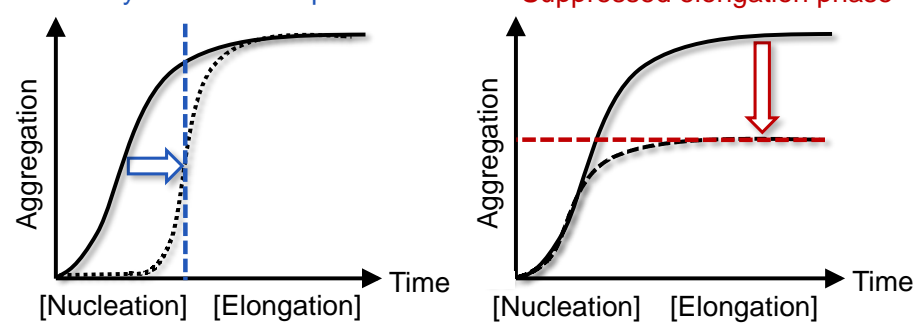

Aggregation amounts are unchanged,
while nucleation phase is delayed."

Onset of nucleation phase is unchanged, while aggregation amounts are decreased."

(b)

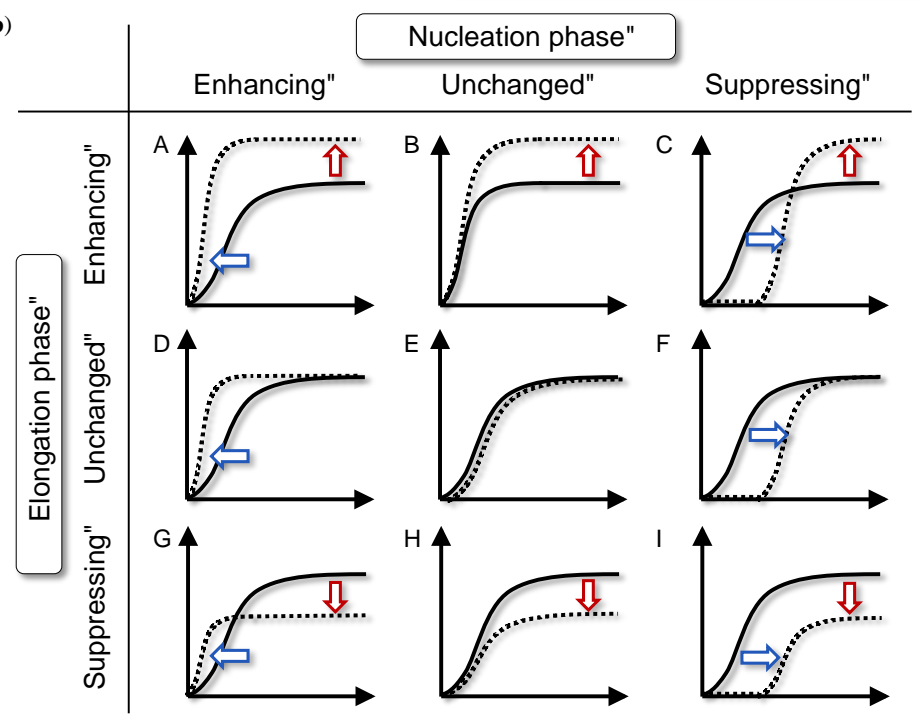

Figure 1. (a) Nucleation-dependent polymerization mechanism of amyloid $\beta 42$ (A $\beta 42$ ). The elongation phase is assumed to consist of "on"-pathway and "off"-pathway into fibrillization. (b) Categorization of nine types of modulators of $A \beta 42$ aggregation focusing on the nucleation and elongation phases. In (b), only on-pathway route is indicated.

\subsection{Classification of Aggregation Inhibitors}

The nucleation phase involves the rate-limiting formation of oligomeric species associated with a lag time, in contrast with the elongation phase. The formation of oligomers that are kinetically competent to form fibrils occurs via a mechanism involving nucleated conformational conversion [32]. Because toxic oligomers could form kinetically competent nuclei, we consider the nucleation phase as a target for inhibition. Considering nine possible combinations of modulator patterns (Figure 1b), three types of modulators (" $\mathrm{C}$, , "F," and "I") that delay the initiation of nuclei formation need to be focused on. It is important to systematically understand the rationale based on an organized analysis of how $A \beta$ aggregation is suppressed.

Furthermore, another critical issue concerns how to prepare $A \beta$ protein in a buffer solution when performing aggregation tests. In sodium dodecyl sulfate-polyacrylamide gel electrophoresis (SDS-PAGE), A $\beta 42$ in a buffer solution produced predominantly not only a monomer but also a broad trimer or tetramer, which are assumed to be an SDS-induced artifact [33,34]. Since even fresh A $\beta$ protein contains nuclei that are inevitably formed during HPLC purification and/or storage, A $\beta 42$ likely aggregates very quickly to form larger nuclei. To evaluate $\mathrm{A} \beta 42$ aggregation, a sequential-type 
aggregation test using $\mathrm{A} \beta 42$ treated with 1,1,1,3,3,3-hexafluoro-2-propanol (HFIP), known as an $\alpha$-helix inducer to dissociate $\beta$-sheet-contained nuclei [35], is useful. It must be noted that HFIP-treated $\mathrm{A} \beta 42$ forms a $\alpha$-helix structure (but not a random structure) even before aggregation [36]. Indeed, Hiroaki and coworkers raised the problem that HFIP usage is not enough to dissolve A $\beta 42$ nuclei into monomers (remaining as dimers) based on NMR studies [37].

\section{Structural Features of Anti-A $\beta 42$ Aggregative Compounds}

\subsection{Catechol-Type Flavonoid: Catechol Moiety}

Most compounds with anti-aggregative properties against amyloidogenic proteins share a catechol moiety, which is also related to anti-oxidative stress, as exemplified by (+)-taxifolin, myricetin, quercetin, (+)-catechin, epigallocatechin gallate (EGCG), and rosmarinic acid [14,38-40]. Fink and coworkers first identified the possible significance of the $o$-quinone moiety of baicalein having the catechol structure in the A-ring for suppressing $\alpha$-synuclein aggregation, which is responsible for Parkinson's disease [41]. Kelly and coworkers also suggested the contribution of the oxidation product formed between EGCG and A $\beta 40$ to the remodeling of preformed fibrils [42], but the structure of the oxidation product has not been identified. Lim and coworkers have comprehensively elucidated the mode of action underlying how unique compounds inhibit $A \beta 40$ or $A \beta 42$ aggregation by focusing on EGCG, myricetin, curcumin, nordihydroguaiaretic acid, rosmarinic acid, and ferulic acid [43-46]. To enhance the bioavailability of aggregation inhibitors, the linkage approach in order to design bivalent multifunctional compounds by conjugating cholesterol was adopted [47]. Notably, the existence of a catechol moiety in aminoisoflavones could be implicated in the differentiation of binding modes between aminoisoflavones and $\mathrm{A} \beta 40$ [45].

Irie and coworkers demonstrated through systematic studies the role of the catechol moiety in preventing the aggregation of $\mathrm{A} \beta 42$, which has greater toxicity than $\mathrm{A} \beta 40$ aggregation. The $o$-quinone structure in the B-rings of (+)-taxifolin can target Lys16 and 28-A 342 via a Michael adduct, but not a Schiff base (Figure 2a) by targeting the elongation phase (categorized as "I" in Figure 1b) [38]. Ginex et al. validated the binding of (+)-taxifolin to the hydrophobic groove near Lys16 and Glu22, and suggested that this binding may proceed through the nucleophilic attack of the deprotonated amino group on the side chain of Lys16 [48]. Recently, the therapeutic potential of (+)-taxifolin was uncovered using a mouse model (Tg-SwDI mice) for cerebral amyloid angiopathy [49,50]; (+)-taxifolin was found to downregulate $\mathrm{A} \beta$-related inflammation using laser speckle flowmetry to measure cerebral blood flow, as summarized in Table 1. This downregulation involves the modulation of the triggering receptor expressed on myeloid cell 2 (TREM2). 


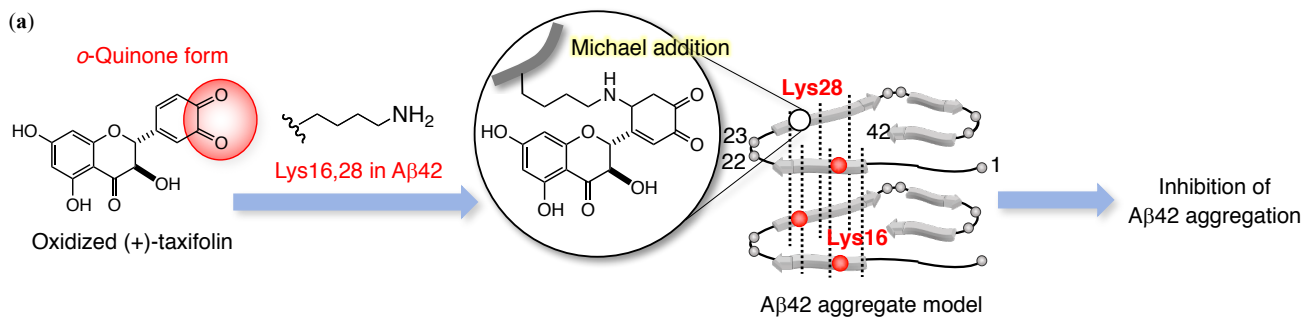

(b)
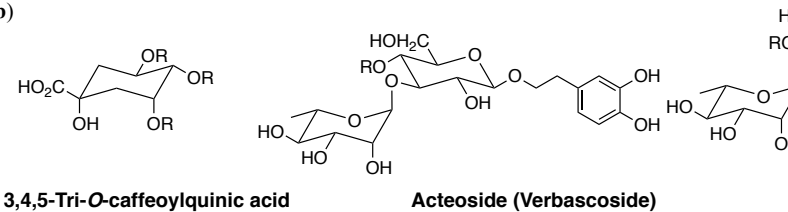

3,4,5-Tri-O-caffeoylquinic acid

Acteoside (Verbascoside)

Oraposide
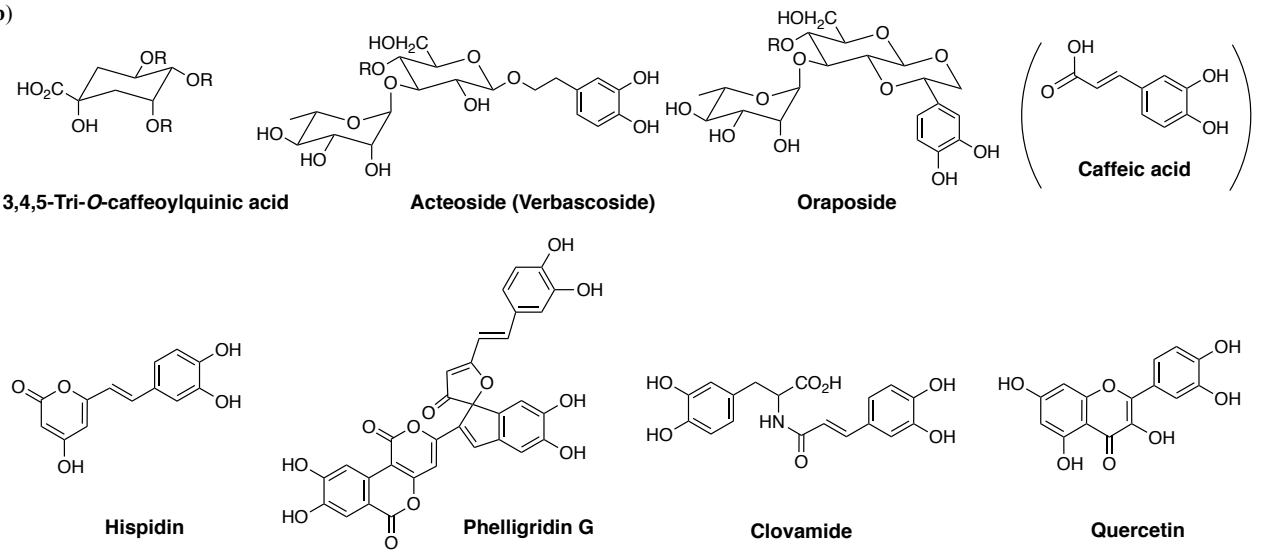

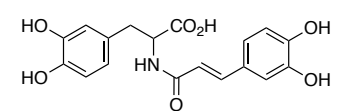

Clovamide<smiles>O=c1c(O)c(-c2ccc(O)cc2O)oc2cc(O)cc(O)c12</smiles>

Quercetin

Figure 2. (a) Michael adduct of catechol-type flavonoids with Lys16 and 28 in A $\beta 42$. (b) Catechol-type compounds from natural products by Shigemori and coworkers, which have anti-A $\beta 42$ aggregation properties. $\mathrm{R}=$ caffeate.

Shigemori and coworkers have carried out intensive studies on aggregation inhibitors of $A \beta 42$ with a catechol moiety (Figure 2b). Caffeoylquinic acid is found in sweet potatoes, propolis, and coffee beans, and 3,4,5-tri-O-caffeoylquinic acid is a most potent analogue [51]. Acteoside [52] from Orobanche minor includes both caffeoyl acid and hydroxytyrosol, whereas oraposide [53] from Orobanche minor, hispidin and phelligridins [54] from Inonotus obliquus, and clovamide [55] from Trifolium pratense contain caffeoyl acid alone. Moreover, quercetin and its glycoside [56] are anti-oxidant flavonoids found in Tamarix gallica.

\subsection{Non-Catechol-Type Flavonoid: Planarity}

Several non-catechol-type compounds show potent inhibitory activities against $\mathrm{A} \beta 42$ aggregation. Solid-state NMR studies by Masuda et al. suggested a significant interaction between curcumin and the benzene rings of Phe19 and 20 in A 342 aggregates due to its intrinsic planarity and hydrophobicity, which allows it to interfere with the elongation phase [57] (Figure 3a). Richard et al. proposed the involvement of $\varepsilon$-viniferin glucoside, a non-catechol polyphenol, in the aromatic interaction between His13 and 14, and Phe19 and 20 of $A \beta 40$ [58]. This interaction is related to the flatness derived from the aromaticity conjugated with an $\alpha, \beta$-unsaturated ketone. 

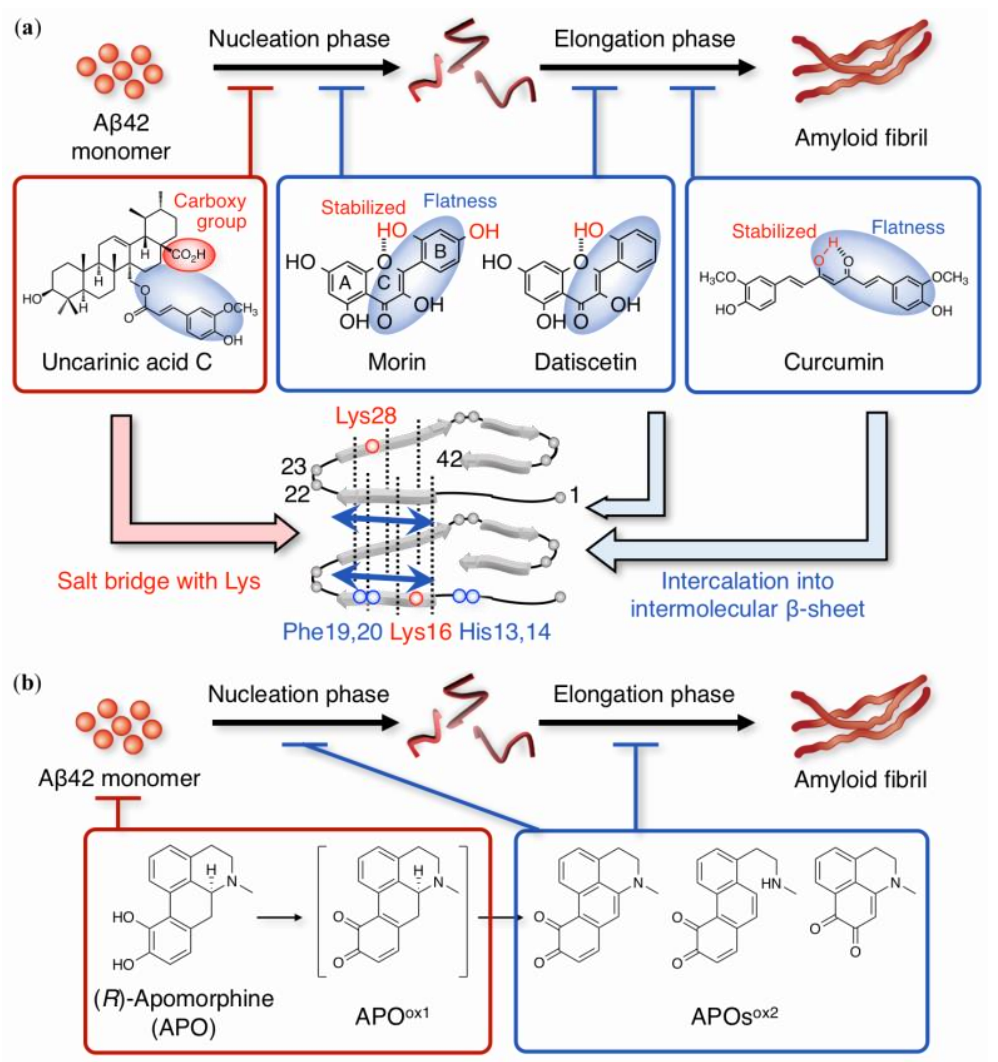

Figure 3. (a) Overview of aggregation inhibitors of non-catechol-type flavonoids. Morin and datiscetin inhibited both nucleation and elongation phases during the aggregation of $A \beta 42$ by interacting with His13 and 14, and Phe19 and 20. (b) Mechanism of A $\beta 42$ aggregation suppression by apomorphine (APO): $\mathrm{APO}$ is first autoxidized to the labile form $\left(\mathrm{APO}^{\mathrm{ox} 1}\right)$, which includes $o$-quinone and has a biphenyl structure; $\mathrm{APO}^{\mathrm{ox} 1}$ forms the Michael adduct with Lys16 and 28 in monomeric A $\beta 42$ during the nucleation phase, leading to the production of a secondary oxidized form (APOs ${ }^{\text {ox } 2}$ ) during both nucleation and elongation phases. In $(\mathbf{a}, \mathbf{b})$, only the on-pathway route is indicated.

Morin and datiscetin are planar compounds similar to curcuminoids due to their aromatic B-ring and $\alpha, \beta$-unsaturated ketone on the C-ring. Morin and datiscetin could affect both the nucleation and elongation phases (as "I") [59], unlike curcumin (as "H") [57]. Such a difference may be deduced from the difference in molecular sizes between flavonoid and curcuminoid. Intramolecular hydrogen bonding between the C-1 oxygen of the C-ring and the 2'-hydroxyl group of the B-ring can probably participate in stabilizing the flatness between the A-, B-, and C-rings. Indeed, the anti-aggregative ability of kaempferol, which lacks a 2'-hydroxyl group, is weaker than that of morin and datiscetin. Given that galangin, without the hydroxyl groups in the B-ring, is inactive, at least one hydroxyl group in the B-ring could be essential to its anti-aggregative ability [59]. ${ }^{1} \mathrm{H}-{ }^{15} \mathrm{~N}$ heteronuclear multiple quantum coherence (HMQC) NMR with band-selective optimized-flip-angle short-transient (SOFAST) [60] suggested the common target residues His 13 and 14, and Phe19 and 20 even in monomeric A $\beta 42$ (Figure 3a). The involvement of these residues does not contradict the observation that intermolecular $\beta$-sheet regions (Gln15-Ala21 and Val24-Ile32) can form in A $\beta 42$ aggregates (i.e., oligomers [61-65]), and that His13 and 14 act as coordinating sites of metal ions together with the ability to form the phenoxyl radical of Tyr10 and can trigger A $\beta 42$ aggregation [66]. Regarding morin, there is one preclinical report on its attenuation of $A \beta$-related neuropathologies and cognitive impairment in APPswe/PS1dE9 mice [67] (Table 1).

Ano and coworkers reported on the prevention of several AD-related pathologies by iso- $\alpha$-acids containing an $\alpha, \beta$-unsaturated ketone, which are bitter components of beer, using a mouse model for $\mathrm{AD}$ [68]. Hisatsune and coworkers discovered the potential of $\beta$-alanyl-L-histidine (carnosine) in 
rescuing cognitive decline related to AD pathology [69]. Considering that carnosine, known as an endogenous anti-oxidant, is abundant in the brain, chicken meat may be a promising functional food, possibly because His residues may interfere with the regions rich in $\pi$ electrons in A $\beta 42$ aggregates.

$(R)$-Apomorphine, a dehydrated morphine, is a unique example whose target can vary depending on its oxidation states. Although $(R)$-apomorphine is known as a dopaminergic agonist in the treatment of Parkinson's disease due to its potent anti-oxidant activity [70], we focused on the conjugated structure of $(R)$-apomorphine by autoxidation [71]. The extension of the conjugated system (isoquinoline skeleton) by autoxidation of the catechol moiety can enhance its planarity, leading to the retardation of further nuclei formation (Figure $3 b)$. NMR studies showed that the first oxidized structure $\left(\mathrm{APO}^{\text {ox1 }}\right)$ of $^{\text {. }}$ $(R)$-apomorphine can target Lys16 to form a Michael adduct in the nucleation phase. Coordinated structural changes can induce the generation of a secondary oxidized form (APO ${ }^{\text {ox } 2}$ ), resulting in their intercalation into intermolecular $\beta$-sheet regions during the elongation phase (Figure 3b). Ohyagi and coworkers reported preclinical studies showing that $(R)$-apomorphine stimulated the degradation of intracellular $A \beta$ [72] and mitigated the depositions of intracellular $A \beta$ [73] in a 3xTg-AD mouse model (Table 1).

Table 1. Preclinical studies of compounds in this review using Alzheimer's disease (AD) model mice.

\begin{tabular}{|c|c|c|c|c|c|}
\hline Drug & Mouse & $\mathrm{A} \beta$ Pathology & Memory Loss & Remarks & Ref. \\
\hline (+)-Taxifolin & Tg-SwDI & $\begin{array}{l}\text { SP, oligomer } \\
\text { decreased }\end{array}$ & $\begin{array}{c}\text { Improved } \\
(\mathrm{MWM})\end{array}$ & $\begin{array}{l}\text { Impaired CBF } \\
\text { restored }\end{array}$ & {$[49,50]$} \\
\hline Morin & APPswe/PS1dE9 & $\begin{array}{c}\mathrm{SP}, \mathrm{A} \beta \\
\text { production } \\
\text { decreased }\end{array}$ & $\begin{array}{l}\text { Improved } \\
(\mathrm{MWM})\end{array}$ & Tau-P decreased & [67] \\
\hline$(R)$-Apomorphine & 3xTg-AD & $\begin{array}{l}\text { SP, intracellular } \\
\text { A } \beta \text { decreased }\end{array}$ & $\begin{array}{l}\text { Improved } \\
\text { (MWM) }\end{array}$ & Tau-P decreased & {$[72,73]$} \\
\hline
\end{tabular}

Abbreviations: CBF, cerebral blood flow; MWM, Morris water maze; SP, senile plaque; Tau-P, tau phosphorylation.

\subsection{Triterpenoid Carboxy Acid: Carboxy Group}

As a third structural factor, the role of the carboxy group in anti-aggregative ability is well documented (e.g., $\alpha$-D-mannosyl-glycerate [74] or flurbiprofen [75]). Actually, we validated the potential of uncarinic acids A-D such as triterpenoid carboxy acids [76] from Uncaria rhynchophylla, also known as chotoko (a shoyaku), which are specific inhibitors of the nucleation phase. Uncarinic acids $\mathrm{A}-\mathrm{D}$ are categorized as "F" or " $\mathrm{I}$ " in the inhibition patterns of Figure $2 \mathrm{~b}$. The structure-activity studies of uncarinic acid C (Figure $4 a$ ), which is able to prevent $A \beta 42$-associated neurotoxicity, showed both a C-27 ferulate and a C-28 carboxylic acid group to be important for its inhibitory activities. According to SOFAST HMQC in NMR and ion mobility-mass spectrometry (IM-MS) combined with native ionization techniques, these inhibitor activities could be associated with the formation of a salt bridge with Lys16, resulting in the prevention of dimer or trimer formation, which can be a possible minimum unit of toxic oligomers ( 2 or $3 \times n$-mer) [36]. The flatness derived from C-27 ferulate may also participate in the interaction with either monomeric $A \beta 42$ or its aggregates. 
(a)

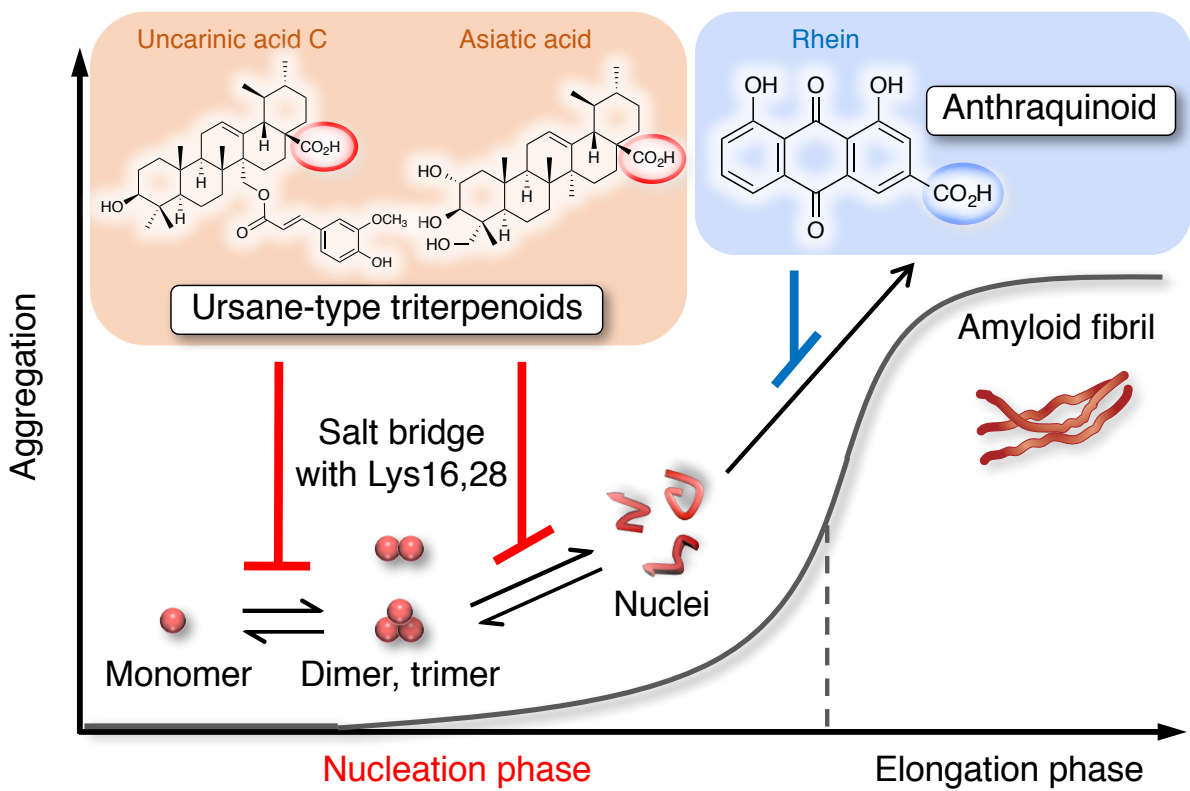

(b)

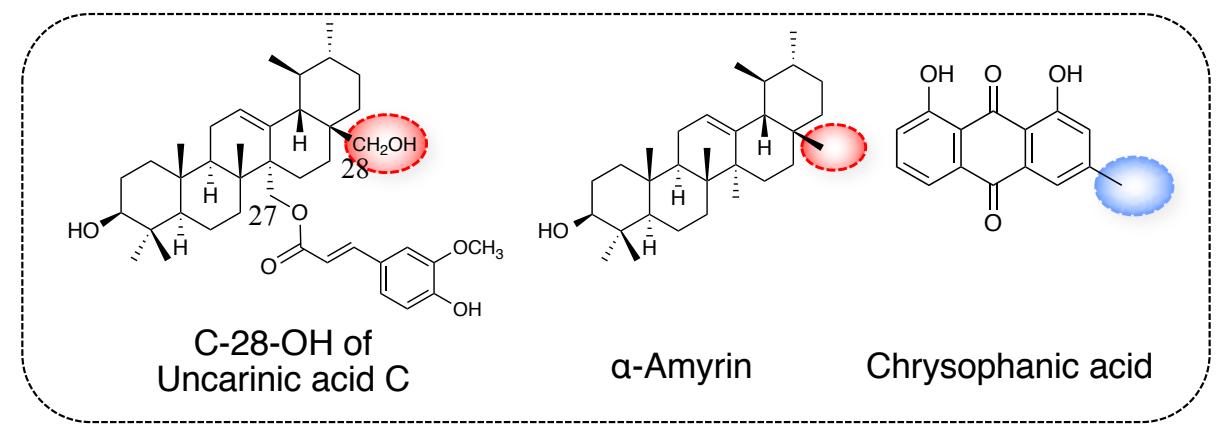

Inactive congeners

Figure 4. (a) Overview of aggregation inhibitors with ion bridge formation of their carboxy group with basic amino acids in A $\beta 42$ (only on-pathway route is indicated). (b) Their inactive congeners as an ursane-type triterpenoid or an anthraquinoid.

Ion mobility-mass spectrometry (IM-MS) is a powerful tool for measuring metastable oligomers to detect individual ions dependent on molecular size and drift time because of the inherent tendency of native oligomers to form structurally heterogeneous assemblies with the same mass-to-charge ratio $(\mathrm{m} / \mathrm{z})$ [77-79]; IM-MS can clearly separate these assemblies despite their identical $\mathrm{m} / \mathrm{z}$ ratios in place of conventional techniques such as SDS-PAGE, size exclusion chromatography, and photo-induced cross-linking, as reviewed in Reference [80]. The unnecessity of using organic solvents that disrupt the non-covalent interactions within the $A \beta$ oligomers is one of the merits of this tool. Intriguingly, the use of SDS causes the overestimation or underestimation of the amount of oligomer because SDS likely induces or interferes with $\mathrm{A} \beta$ oligomerization [81,82]. Comparing the arrival time distribution of each signal ( $z / n ; z$ denotes charge, $n$ denotes the number of oligomers), peaks corresponding to oligomeric orders can be assigned to the series of multivalent ions at least up to 24-mer [83]. IM-MS was also applied to the screening method of aggregation inhibitors to classify small molecules with anti-aggregation of $\mathrm{A} \beta 40$ into specific (e.g., EGCG), non-specific (e.g., tramiprosate), colloidal (e.g., congo red), or non-interacting (e.g., hemin) [79].

To further investigate the contribution of the carbon skeleton with a carboxy group, asiatic acid (ursane-type triterpenoid skeleton) from Centella asiatica in gotu kola and rhein (anthraquinoid skeleton) from Rheum palmatum in daio were selected together with $\alpha$-amyrin and chrysophanic acid as the corresponding comparators [36] (Figure 4b). Asiatic acid retarded the nucleation of A $\beta 42$, also focusing 
on the dimer or trimer, despite lacking a ferulate moiety. In contrast, such activity was diminished in $\alpha$-amyrin. Maslinic acid, a similar triterpenoic acid, has been shown to protect against apoptosis induced by $\mathrm{A} \beta 42$ [84]. Rhein, categorized as either " $\mathrm{H}$ " or " $\mathrm{I}$," inhibited the elongation phase more than the nucleation phase because of the prioritized planarity originating from its anthraquinone skeleton. Actually, chrysophanic acid prevented the elongation as " $\mathrm{H}$," albeit with a slightly weaker inhibition of nucleation than $\alpha$-amyrin. These findings validate the preferable effects of the carboxy groups of triterpenoids in attenuating toxic nuclei-driven oligomerization.

\section{In Vivo Metabolism of Anti-A $\beta 42$ Aggregative Compounds}

Despite the efforts of many researchers, no A $\beta$ aggregation inhibitors that have ever been listed in clinical trials can completely meet the demands of pharmaceutical manufacturers [4]. Although sodium oligomannurarate (GV-971, a marine glycan-derived drug; ClinicalTrials.gov Identifier: NCT02293915) from a Chinese company currently in a Phase III trial is attracting attention (Xiao, S. et al. Phase 3 clinical trial for a novel and multi-targeted oligosaccharide in patients with mild-moderate AD in China (abstract OC3), presented at the 11th Clinical Trials on Alzheimer's Disease, Barcelona, Spain, 2018), most principal clinical studies of natural products have failed. These failed studies include EGCG from green tea (ClinicalTrials.gov Identifier: NCT00951834; trial results were not published, but see Reference [85]), scyllo-inositol from coconut palm (e.g., ClinicalTrials.gov Identifier: NCT01735630) [86], and curcumin from turmeric (e.g., ClinicalTrials.gov Identifier: NCT00099710) [87] (Table 2). According to the paper by Nelson et al. [88], curcumin has never shown effective outcomes in randomized, placebo-controlled clinical trials [89]. This is thought to be due to its instability and low bioavailability, as curcumin abundantly exists as a glucuronide and sulfate conjugates of metabolized or degraded forms in blood and excretions [88]. Considering the $\mathrm{p} K_{\mathrm{a}}$ values (8.5-10.4) of curcumin, the transformation into the phenolate form in water can easily lead to its degradation to vanillin, ferulic acid, and feruloylmethane at neutral and alkaline $\mathrm{pH}$. Accordingly, the amount of intact curcumin in the brain is too small to be detected.

Table 2. Failed clinical studies of natural products targeting A $\beta$ aggregation.

\begin{tabular}{cccccc}
\hline Drug & Patient & Enrollment & Phase & Outcome & $\begin{array}{c}\text { ClinicalTrials } \\
\text { ID }\end{array}$ \\
\hline EGCG & Early AD & 21 & II, III & Insufficient efficacy & NCT00951834 \\
scyllo-inositol & Moderate to severe AD & 350 & II & Insufficient efficacy & NCT01735630 \\
(ELND005) & Mild to moderate AD & 33 & II & Insufficient efficacy & NCT00099710 \\
Curcumin C3 Complex & Min
\end{tabular}

Abbreviations: AD, Alzheimer's disease; EGCG, epigallocatechin gallate.

Meanwhile, curcumin may affect the composition of the gut microbiota, possibly leading to an alteration in brain-gut interaction [90]. There is a growing interest in the preventive role of intestinal microbiota against several lifestyle diseases including neurodegenerative disorders. Minter et al. identified the therapeutic potential of antibiotic-induced perturbations of gut microbial diversity in the pathology of AD [91]. Several studies on the metabolites of dietary fibers by intestinal microbiota in the colon have identified short-chain fatty acids (less than C5) such as valeic acid, isovaleric acid, isobutyric acid, butyric acid, propionic acid, acetic acid, and formic acid, which serve as substrates for energy resources [92,93]. Actually, these short-chain fatty acids attenuated the oligomer formation of $A \beta 40$ and $A \beta 42$ in vitro [94]. In contrast, there is an opposing report that the absence of gut microbiota reduced A $\beta$-related pathology in a mouse model for AD [95]. Further studies will be required to resolve these controversial issues regarding what kinds of microbiota can make major contributions to $\mathrm{AD}$ and other neurodegenerative disorders.

In general, it is reported that $0 \sim 60 \%$ of flavonoids are absorbed in the small intestinal and their half-lives are between 2 and $28 \mathrm{~h}$ [96]. In the following metabolism, absorbed flavonoids can go through first pass Phase II, thereby transforming into methylated, sulfated, and glucuronated forms 
in plasma. These alternations may mutually affect the activity of cytochrome P450 [97]. In positron emission tomography studies by Kan and coworkers, a small amount $(<1 \%)$ of intravenous-injected nobiletin was detected [98]. One could argue about what percentage of administered compounds is needed for therapeutic effects in the brain. Too many doses for administration to increase uptake may lead to unknown side effects in digestive organs. Recently, there are two reports that support underappreciated thinking that brain-targeted compounds do not always need to go through the blood-brain barrier to exert an effect. Cote et al. [99] and Duca et al. [100]. suggested a new role of resveratrol and metformin in duodenal energy sensing in the gut-brain-liver communication axis.

\section{Conclusions and Perspective}

To conclude, we offer three structural factors required for suppressing $A \beta 42$ aggregation including oligomerization, thereby paving the way for future research to design disease-modifying drugs such as toxic oligomer-targeted inhibitors. Moreover, this knowledge could be useful for predicting whether natural products have the ability to inhibit $A \beta 42$ aggregation. Essentially, it should be noted that these factors may also determine whether the nucleation or elongation phases are targeted. The most-targeted amino acid residues in A 342 aggregates include Lys16 and 28 for Michael addition and ion-bridge formation, and His13 and 14 as well as Phe19 and 20 for intercalation. Most of these residues are localized in $\beta$-sheet regions [62]. Recently, prion-like cell-to-cell transmission of $A \beta$ oligomers was identified as one potential mechanism by which the toxicity of $A \beta$ oligomers could spread [101]. The impact of the metabolites of test compounds together with their pharmacokinetics, blood-brain barrier permeability, and effective conjugate forms must be thus explored through further cell culture or in vivo experiments.

Funding: This study was partly supported by the JSPS KAKENHI, grant number 26221202 to K.I. and K.M., and 16H06194 to K.M.

Conflicts of Interest: The authors declare no conflict of interest.

\section{References}

1. Haass, C.; Selkoe, D.J. Soluble protein oligomers in neurodegeneration: Lessons from the Alzheimer's amyloid $\beta$-peptide. Nat. Rev. Mol. Cell Biol. 2007, 8, 101-112. [CrossRef] [PubMed]

2. Hardy, J.A.; Higgins, G.A. Alzheimer's disease: The amyloid cascade hypothesis. Science 1992, 256, $184-185$. [CrossRef] [PubMed]

3. Karran, E.; Mercken, M.; De Strooper, B. The amyloid cascade hypothesis for Alzheimer's disease: An appraisal for the development of therapeutics. Nat. Rev. Drug Discov. 2011, 10, 698-712. [CrossRef] [PubMed]

4. Panza, F.; Lozupone, M.; Logroscino, G.; Imbimbo, B.P. A critical appraisal of amyloid- $\beta$-targeting therapies for Alzheimer disease. Nat. Rev. Neurol. 2019, 15, 73-88. [CrossRef] [PubMed]

5. Glenner, G.G.; Wong, C.W. Alzheimer's disease: Initial report of the purification and characterization of a novel cerebrovascular amyloid protein. Biochem. Biophys. Res. Commun. 1984, 120, 885-890. [CrossRef]

6. Masters, C.L.; Simms, G.; Weinman, N.A.; Multhaup, G.; McDonald, B.L.; Beyreuther, K. Amyloid plaque core protein in Alzheimer disease and Down syndrome. Proc. Natl. Acad. Sci. USA 1985, 82, 4245-4249. [CrossRef] [PubMed]

7. Roychaudhuri, R.; Yang, M.; Hoshi, M.M.; Teplow, D.B. Amyloid $\beta$-protein assembly and Alzheimer disease. J. Biol. Chem. 2009, 284, 4749-4753. [CrossRef] [PubMed]

8. Benilova, I.; Karran, E.; De Strooper, B. The toxic A $\beta$ oligomer and Alzheimer's disease: An emperor in need of clothes. Nat. Neurosci. 2012, 15, 349-357. [CrossRef] [PubMed]

9. Harper, J.D.; Wong, S.S.; Lieber, C.M.; Lansbury, P.T. Observation of metastable A $\beta$ amyloid protofibrils by atomic force microscopy. Chem. Biol. 1997, 4, 119-125. [CrossRef]

10. Walsh, D.M.; Lomakin, A.; Benedek, G.B.; Condron, M.M.; Teplow, D.B. Amyloid $\beta$-protein fibrillogenesis. Detection of a protofibrillar intermediate. J. Biol. Chem. 1997, 272, 22364-22372. [CrossRef] [PubMed] 
11. Lambert, M.P.; Barlow, A.K.; Chromy, B.A.; Edwards, C.; Freed, R.; Liosatos, M.; Morgan, T.E.; Rozovsky, I.; Trommer, B.; Viola, K.L.; et al. Diffusible, nonfibrillar ligands derived from A $\beta 1-42$ are potent central nervous system neurotoxins. Proc. Natl. Acad. Sci. USA 1998, 95, 6448-6453. [CrossRef] [PubMed]

12. Hoshi, M.; Sato, M.; Matsumoto, S.; Noguchi, A.; Yasutake, K.; Yoshida, N.; Sato, K. Spherical aggregates of $\beta$-amyloid (amylospheroid) show high neurotoxicity and activate tau protein kinase I/glycogen synthase kinase-3ß. Proc. Natl. Acad. Sci. USA 2003, 100, 6370-6375. [CrossRef] [PubMed]

13. Williams, R.J.; Spencer, J.P. Flavonoids, cognition, and dementia: Actions, mechanisms, and potential therapeutic utility for Alzheimer disease. Free Radic. Biol. Med. 2012, 52, 35-45. [CrossRef] [PubMed]

14. Ono, K.; Hamaguchi, T.; Naiki, H.; Yamada, M. Anti-amyloidogenic effects of antioxidants: Implications for the prevention and therapeutics of Alzheimer's disease. Biochim. Biophys. Acta 2006, 1762, 575-586. [CrossRef] [PubMed]

15. Yamin, G.; Ono, K.; Inayathullah, M.; Teplow, D.B. Amyloid $\beta$-protein assembly as a therapeutic target of Alzheimer's disease. Curr. Pharm. Design 2008, 14, 3231-3246. [CrossRef]

16. Williams, P.; Sorribas, A.; Howes, M.J. Natural products as a source of Alzheimer's drug leads. Nat. Prod. Rep. 2011, 28, 48-77. [CrossRef] [PubMed]

17. Ushikubo, H.; Watanabe, S.; Tanimoto, Y.; Abe, K.; Hiza, A.; Ogawa, T.; Asakawa, T.; Kan, T.; Akaishi, T. 3,3', 4',5,5'-Pentahydroxyflavone is a potent inhibitor of amyloid $\beta$ fibril formation. Neurosci. Lett. 2012. [CrossRef]

18. Nabavi, S.F.; Braidy, N.; Habtemariam, S.; Orhan, I.E.; Daglia, M.; Manayi, A.; Gortzi, O.; Nabavi, S.M. Neuroprotective effects of chrysin: From chemistry to medicine. Neurochem. Int. 2015, 90, 224-231. [CrossRef]

19. Habtemariam, S. Rutin as a natural therapy for Alzheimer's disease: Insights into its mechanisms of action. Curr. Med. Chem. 2016, 23, 860-873. [CrossRef]

20. Nabavi, S.F.; Braidy, N.; Habtemariam, S.; Sureda, A.; Manayi, A.; Nabavi, S.M. Neuroprotective effects of fisetin in Alzheimer's and Parkinson's diseases: From chemistry to medicine. Curr. Top Med. Chem. 2016, 16, 1910-1915. [CrossRef]

21. Braidy, N.; Jugder, B.E.; Poljak, A.; Jayasena, T.; Mansour, H.; Nabavi, S.M.; Sachdev, P.; Grant, R. Resveratrol as a potential therapeutic candidate for the treatment and management of Alzheimer's disease. Curr. Top Med. Chem. 2016, 16, 1951-1960. [CrossRef] [PubMed]

22. Kumar, A.; Singh, A.; Aggarwal, A. Therapeutic potentials of herbal drugs for Alzheimer's disease-An overview. Indian J. Exp. Biol. 2017, 55, 63-73. [PubMed]

23. Nabavi, S.F.; Khan, H.; D'Onofrio, G.; Samec, D.; Shirooie, S.; Dehpour, A.R.; Arguelles, S.; Habtemariam, S.; Sobarzo-Sanchez, E. Apigenin as neuroprotective agent: Of mice and men. Pharmacol. Res. 2018, 128, 359-365. [CrossRef] [PubMed]

24. Hasegawa, K.; Yamaguchi, I.; Omata, S.; Gejyo, F.; Naiki, H. Interaction between A $\beta(1-42)$ and A $\beta(1-40)$ in Alzheimer's $\beta$-amyloid fibril formation in vitro. Biochemistry 1999, 38, 15514-15521. [CrossRef] [PubMed]

25. Serio, T.R.; Cashikar, A.G.; Kowal, A.S.; Sawicki, G.J.; Moslehi, J.J.; Serpell, L.; Arnsdorf, M.F.; Lindquist, S.L. Nucleated conformational conversion and the replication of conformational information by a prion determinant. Science 2000, 289, 1317-1321. [CrossRef] [PubMed]

26. Bush, A.I. The metallobiology of Alzheimer's disease. Trends Neurosci. 2003, 26, 207-214. [CrossRef]

27. Frederickson, C.J.; Koh, J.Y.; Bush, A.I. The neurobiology of zinc in health and disease. Nat. Rev. Neurosci. 2005, 6, 449-462. [CrossRef]

28. Kotler, S.A.; Walsh, P.; Brender, J.R.; Ramamoorthy, A. Differences between amyloid- $\beta$ aggregation in solution and on the membrane: Insights into elucidation of the mechanistic details of Alzheimer's disease. Chem. Soc. Rev. 2014, 43, 6692-6700. [CrossRef]

29. Kim, J.; Basak, J.M.; Holtzman, D.M. The role of apolipoprotein E in Alzheimer's disease. Neuron 2009, 63, 287-303. [CrossRef]

30. Meyer-Luehmann, M.; Spires-Jones, T.L.; Prada, C.; Garcia-Alloza, M.; de Calignon, A.; Rozkalne, A.; Koenigsknecht-Talboo, J.; Holtzman, D.M.; Bacskai, B.J.; Hyman, B.T. Rapid appearance and local toxicity of amyloid- $\beta$ plaques in a mouse model of Alzheimer's disease. Nature 2008, 451, 720-724. [CrossRef]

31. Bieschke, J.; Herbst, M.; Wiglenda, T.; Friedrich, R.P.; Boeddrich, A.; Schiele, F.; Kleckers, D.; Lopez del Amo, J.M.; Gruning, B.A.; Wang, Q.; et al. Small-molecule conversion of toxic oligomers to nontoxic $\beta$-sheet-rich amyloid fibrils. Nat. Chem. Biol. 2011, 8, 93-101. [CrossRef] [PubMed] 
32. Lee, J.; Culyba, E.K.; Powers, E.T.; Kelly, J.W. Amyloid- $\beta$ forms fibrils by nucleated conformational conversion of oligomers. Nat. Chem. Biol. 2011, 7, 602-609. [CrossRef] [PubMed]

33. Bitan, G.; Fradinger, E.A.; Spring, S.M.; Teplow, D.B. Neurotoxic protein oligomers-what you see is not always what you get. Amyloid 2005, 12, 88-95. [CrossRef] [PubMed]

34. Hepler, R.W.; Grimm, K.M.; Nahas, D.D.; Breese, R.; Dodson, E.C.; Acton, P.; Keller, P.M.; Yeager, M.; Wang, H.; Shughrue, P.; et al. Solution state characterization of amyloid $\beta$-derived diffusible ligands. Biochemistry 2006, 45, 15157-15167. [CrossRef] [PubMed]

35. Teplow, D.B. Preparation of amyloid $\beta$-protein for structural and functional studies. Methods Enzymol. 2006, $413,20-33$.

36. Murakami, K.; Yoshioka, T.; Horii, S.; Hanaki, M.; Midorikawa, S.; Taniwaki, S.; Gunji, H.; Akagi, K.I.; Kawase, T.; Hirose, K.; et al. Role of the carboxy groups of triterpenoids in their inhibition of the nucleation of amyloid $\beta 42$ required for forming toxic oligomers. Chem. Commun. 2018, 54, 6272-6275. [CrossRef]

37. Shigemitsu, Y.; Iwaya, N.; Goda, N.; Matsuzaki, M.; Tenno, T.; Narita, A.; Hoshi, M.; Hiroaki, H. Nuclear magnetic resonance evidence for the dimer formation of $\beta$ amyloid peptide 1-42 in 1,1,1,3,3,3-hexafluoro-2-propanol. Anal. Biochem. 2016, 498, 59-67. [CrossRef]

38. Sato, M.; Murakami, K.; Uno, M.; Nakagawa, Y.; Katayama, S.; Akagi, K.; Masuda, Y.; Takegoshi, K.; Irie, K. Site-specific inhibitory mechanism for amyloid $\beta 42$ aggregation by catechol-type flavonoids targeting the Lys residues. J. Biol. Chem. 2013, 288, 23212-23224. [CrossRef]

39. Ono, K.; Yoshiike, Y.; Takashima, A.; Hasegawa, K.; Naiki, H.; Yamada, M. Potent anti-amyloidogenic and fibril-destabilizing effects of polyphenols in vitro: Implications for the prevention and therapeutics of Alzheimer's disease. J. Neurochem. 2003, 87, 172-181. [CrossRef]

40. Ehrnhoefer, D.E.; Bieschke, J.; Boeddrich, A.; Herbst, M.; Masino, L.; Lurz, R.; Engemann, S.; Pastore, A.; Wanker, E.E. EGCG redirects amyloidogenic polypeptides into unstructured, off-pathway oligomers. Nat. Struct. Mol. Biol. 2008, 15, 558-566. [CrossRef]

41. Zhu, M.; Rajamani, S.; Kaylor, J.; Han, S.; Zhou, F.; Fink, A.L. The flavonoid baicalein inhibits fibrillation of $\alpha$-synuclein and disaggregates existing fibrils. J. Biol. Chem. 2004, 279, 26846-26857. [CrossRef] [PubMed]

42. Palhano, F.L.; Lee, J.; Grimster, N.P.; Kelly, J.W. Toward the molecular mechanism(s) by which EGCG treatment remodels mature amyloid fibrils. J. Am. Chem. Soc. 2013, 135, 7503-7510. [CrossRef] [PubMed]

43. Choi, J.S.; Braymer, J.J.; Nanga, R.P.; Ramamoorthy, A.; Lim, M.H. Design of small molecules that target metal-A $\beta$ species and regulate metal-induced $\mathrm{A} \beta$ aggregation and neurotoxicity. Proc. Natl. Acad. Sci. USA 2010, 107, 21990-21995. [CrossRef] [PubMed]

44. DeToma, A.S.; Salamekh, S.; Ramamoorthy, A.; Lim, M.H. Misfolded proteins in Alzheimer's disease and type II diabetes. Chem. Soc. Rev. 2012, 41, 608-621. [CrossRef] [PubMed]

45. DeToma, A.S.; Krishnamoorthy, J.; Nam, Y.; Lee, H.J.; Brender, J.R.; Kochi, A.; Lee, D.; Onnis, V.; Congiu, C.; Manfredini, S.; et al. Synthetic flavonoids, aminoisoflavones: Interaction and reactivity with metal-free and metal-associated amyloid- $\beta$ species. Chem. Sci. 2014, 5, 4851-4862. [CrossRef] [PubMed]

46. Korshavn, K.J.; Jang, M.; Kwak, Y.J.; Kochi, A.; Vertuani, S.; Bhunia, A.; Manfredini, S.; Ramamoorthy, A.; Lim, M.H. Reactivity of metal-free and metal-associated amyloid- $\beta$ with glycosylated polyphenols and their esterified derivatives. Sci. Rep. 2015, 5, 17842. [CrossRef] [PubMed]

47. Lenhart, J.A.; Ling, X.; Gandhi, R.; Guo, T.L.; Gerk, P.M.; Brunzell, D.H.; Zhang, S. “Clicked” bivalent ligands containing curcumin and cholesterol as multifunctional A $\beta$ oligomerization inhibitors: Design, synthesis, and biological characterization. J. Med. Chem. 2010, 53, 6198-6209. [CrossRef] [PubMed]

48. Ginex, T.; Trius, M.; Luque, F.J. Computational study of the aza-michael addition of the flavonoid (+)-taxifolin in the inhibition of $\beta$-amyloid fibril aggregation. Chemistry 2018, 24, 5813-5824. [CrossRef] [PubMed]

49. Saito, S.; Yamamoto, Y.; Maki, T.; Hattori, Y.; Ito, H.; Mizuno, K.; Harada-Shiba, M.; Kalaria, R.N.; Fukushima, M.; Takahashi, R.; et al. Taxifolin inhibits amyloid- $\beta$ oligomer formation and fully restores vascular integrity and memory in cerebral amyloid angiopathy. Acta Neuropathol. Commun. 2017, 5, 26. [CrossRef]

50. Inoue, T.; Saito, S.; Tanaka, M.; Yamakage, H.; Kusakabe, T.; Shimatsu, A.; Ihara, M.; Satoh-Asahara, N. Pleiotropic neuroprotective effects of taxifolin in cerebral amyloid angiopathy. Proc. Natl. Acad. Sci. USA 2019, 116, 10031-10038. [CrossRef] 
51. Miyamae, Y.; Kurisu, M.; Murakami, K.; Han, J.; Isoda, H.; Irie, K.; Shigemori, H. Protective effects of caffeoylquinic acids on the aggregation and neurotoxicity of the 42-residue amyloid $\beta$-protein. Bioorg. Med. Chem. 2012, 20, 5844-5849. [CrossRef] [PubMed]

52. Kurisu, M.; Miyamae, Y.; Murakami, K.; Han, J.; Isoda, H.; Irie, K.; Shigemori, H. Inhibition of amyloid $\beta$ aggregation by acteoside, a phenylethanoid glycoside. Biosci. Biotech. Biochem. 2013, 77, 1329-1332. [CrossRef] [PubMed]

53. Kidachi, E.; Kurisu, M.; Miyamae, Y.; Hanaki, M.; Murakami, K.; Irie, K.; Shigemori, H. Structure-activity relationship of phenylethanoid glycosides on the inhibition of amyloid $\beta$ aggregation. HeteroCycles 2016, 92, 1976-1982.

54. Aihara, Y.; Kawaguchi, A.; Hanaki, M.; Murakami, K.; Irie, K.; Shigemori, H. Inhibitory activity of hispidin derivatives isolated from Inonotus obliquus on amyloid $\beta$ aggregation. HeteroCycles 2017, 94, 1280-1287.

55. Tsunoda, T.; Takase, M.; Shigemori, H. Structure-activity relationship of clovamide and its related compounds for the inhibition of amyloid $\beta$ aggregation. Bioorg. Med. Chem. 2018, 26, 3202-3209. [CrossRef] [PubMed]

56. Ben Hmidene, A.; Hanaki, M.; Murakami, K.; Irie, K.; Isoda, H.; Shigemori, H. Inhibitory activities of antioxidant flavonoids from Tamarix gallica on amyloid aggregation related to Alzheimer's and type 2 diabetes diseases. Biol. Pharm. Bull. 2017, 40, 238-241. [CrossRef] [PubMed]

57. Masuda, Y.; Fukuchi, M.; Yatagawa, T.; Tada, M.; Takeda, K.; Irie, K.; Akagi, K.; Monobe, Y.; Imazawa, T.; Takegoshi, K. Solid-state NMR analysis of interaction sites of curcumin and 42-residue amyloid $\beta$-protein fibrils. Bioorg. Med. Chem. 2011, 19, 5967-5974. [CrossRef]

58. Richard, T.; Papastamoulis, Y.; Waffo-Teguo, P.; Monti, J.P. 3D NMR structure of a complex between the amyloid $\beta$ peptide (1-40) and the polyphenol $\varepsilon$-viniferin glucoside: Implications in Alzheimer's disease. Biochim. Biophys. Acta 2013, 1830, 5068-5074. [CrossRef]

59. Hanaki, M.; Murakami, K.; Akagi, K.; Irie, K. Structural insights into mechanisms for inhibiting amyloid $\beta 42$ aggregation by non-catechol-type flavonoids. Bioorg. Med. Chem. 2016, 24, 304-313. [CrossRef]

60. Schanda, P.; Brutscher, B. Very fast two-dimensional NMR spectroscopy for real-time investigation of dynamic events in proteins on the time scale of seconds. J. Am. Chem. Soc. 2005, 127, 8014-8015. [CrossRef]

61. Morimoto, A.; Irie, K.; Murakami, K.; Ohigashi, H.; Shindo, M.; Nagao, M.; Shimizu, T.; Shirasawa, T. Aggregation and neurotoxicity of mutant amyloid $\beta(\mathrm{A} \beta)$ peptides with proline replacement: Importance of turn formation at positions 22 and 23. Biochem. Biophys. Res. Commun. 2002, 295, 306-311. [CrossRef]

62. Morimoto, A.; Irie, K.; Murakami, K.; Masuda, Y.; Ohigashi, H.; Nagao, M.; Fukuda, H.; Shimizu, T.; Shirasawa, T. Analysis of the secondary structure of $\beta$-amyloid (A $\beta 42)$ fibrils by systematic proline replacement. J. Biol. Chem. 2004, 279, 52781-52788. [CrossRef] [PubMed]

63. Masuda, Y.; Uemura, S.; Ohashi, R.; Nakanishi, A.; Takegoshi, K.; Shimizu, T.; Shirasawa, T.; Irie, K. Identification of physiological and toxic conformations in A $\beta 42$ aggregates. ChemBioChem 2009, 10, $287-295$. [CrossRef] [PubMed]

64. Luhrs, T.; Ritter, C.; Adrian, M.; Riek-Loher, D.; Bohrmann, B.; Dobeli, H.; Schubert, D.; Riek, R. 3D structure of Alzheimer's amyloid- $\beta(1-42)$ fibrils. Proc. Natl. Acad. Sci. USA 2005, 102, 17342-17347. [CrossRef] [PubMed]

65. Xiao, Y.; Ma, B.; McElheny, D.; Parthasarathy, S.; Long, F.; Hoshi, M.; Nussinov, R.; Ishii, Y. A $\beta(1-42)$ fibril structure illuminates self-recognition and replication of amyloid in Alzheimer's disease. Nat. Struct. Mol. Biol. 2015, 22, 499-505. [CrossRef] [PubMed]

66. Murakami, K.; Irie, K.; Ohigashi, H.; Hara, H.; Nagao, M.; Shimizu, T.; Shirasawa, T. Formation and stabilization model of the 42-mer A $\beta$ radical: Implications for the long-lasting oxidative stress in Alzheimer's disease. J. Am. Chem. Soc. 2005, 127, 15168-15174. [CrossRef] [PubMed]

67. Du, Y.; Qu, J.; Zhang, W.; Bai, M.; Zhou, Q.; Zhang, Z.; Li, Z.; Miao, J. Morin reverses neuropathological and cognitive impairments in APPswe/PS1dE9 mice by targeting multiple pathogenic mechanisms. Neuropharmacology 2016, 108, 1-13. [CrossRef] [PubMed]

68. Ano, Y.; Dohata, A.; Taniguchi, Y.; Hoshi, A.; Uchida, K.; Takashima, A.; Nakayama, H. Iso- $\alpha$-acids, bitter components of beer, prevent inflammation and cognitive decline induced in a mouse model of Alzheimer's disease. J. Biol. Chem. 2017, 292, 3720-3728. [CrossRef]

69. Herculano, B.; Tamura, M.; Ohba, A.; Shimatani, M.; Kutsuna, N.; Hisatsune, T. $\beta$-Alanyl-L-histidine rescues cognitive deficits caused by feeding a high fat diet in a transgenic mouse model of Alzheimer's disease. J. Alzheimers Dis. 2013, 33, 983-997. [CrossRef] 
70. Grunblatt, E.; Mandel, S.; Gassen, M.; Youdim, M.B. Potent neuroprotective and antioxidant activity of apomorphine in MPTP and 6-hydroxydopamine induced neurotoxicity. J. Neural Transm. Suppl. 1999, 55, $57-70$.

71. Hanaki, M.; Murakami, K.; Katayama, S.; Akagi, K.I.; Irie, K. Mechanistic analyses of the suppression of amyloid $\beta 42$ aggregation by apomorphine. Bioorg. Med. Chem. 2018, 26, 1538-1546. [CrossRef] [PubMed]

72. Himeno, E.; Ohyagi, Y.; Ma, L.; Nakamura, N.; Miyoshi, K.; Sakae, N.; Motomura, K.; Soejima, N.; Yamasaki, R.; Hashimoto, T.; et al. Apomorphine treatment in Alzheimer mice promoting amyloid- $\beta$ degradation. Ann. Neurol. 2011, 69, 248-256. [CrossRef] [PubMed]

73. Nakamura, N.; Ohyagi, Y.; Imamura, T.; Yanagihara, Y.T.; Iinuma, K.M.; Soejima, N.; Murai, H.; Yamasaki, R.; Kira, J.I. Apomorphine therapy for neuronal insulin resistance in a mouse model of Alzheimer's disease. J. Alzheimers Dis. 2017, 58, 1151-1161. [CrossRef] [PubMed]

74. Ryu, J.; Kanapathipillai, M.; Lentzen, G.; Park, C.B. Inhibition of $\beta$-amyloid peptide aggregation and neurotoxicity by $\alpha$-D-mannosylglycerate, a natural extremolyte. Peptides 2008, 29, 578-584. [CrossRef] [PubMed]

75. Klabunde, T.; Petrassi, H.M.; Oza, V.B.; Raman, P.; Kelly, J.W.; Sacchettini, J.C. Rational design of potent human transthyretin amyloid disease inhibitors. Nat. Struct. Biol. 2000, 7, 312-321.

76. Yoshioka, T.; Murakami, K.; Ido, K.; Hanaki, M.; Yamaguchi, K.; Midorikawa, S.; Taniwaki, S.; Gunji, H.; Irie, K. Semisynthesis and structure-activity studies of uncarinic acid C isolated from Uncaria rhynchophylla as a specific inhibitor of the nucleation phase in amyloid $\beta 42$ aggregation. J. Nat. Prod. 2016, 79, 2521-2529. [CrossRef] [PubMed]

77. Bernstein, S.L.; Dupuis, N.F.; Lazo, N.D.; Wyttenbach, T.; Condron, M.M.; Bitan, G.; Teplow, D.B.; Shea, J.E.; Ruotolo, B.T.; Robinson, C.V.; et al. Amyloid- $\beta$ protein oligomerization and the importance of tetramers and dodecamers in the aetiology of Alzheimer's disease. Nat. Chem. 2009, 1, 326-331. [CrossRef]

78. Kloniecki, M.; Jablonowska, A.; Poznanski, J.; Langridge, J.; Hughes, C.; Campuzano, I.; Giles, K.; Dadlez, M. Ion mobility separation coupled with MS detects two structural states of Alzheimer's disease A $\beta 1-40$ peptide oligomers. J. Mol. Biol. 2011, 407, 110-124. [CrossRef]

79. Young, L.M.; Saunders, J.C.; Mahood, R.A.; Revill, C.H.; Foster, R.J.; Tu, L.H.; Raleigh, D.P.; Radford, S.E.; Ashcroft, A.E. Screening and classifying small-molecule inhibitors of amyloid formation using ion mobility spectrometry-mass spectrometry. Nat. Chem. 2015, 7, 73-81. [CrossRef]

80. Li, H.; Rahimi, F.; Murakami, K.; Maiti, P.; Sinha, S.; Bitan, G. Amyloids and protein aggregation-analytical methods. Encycl. Ana. Chem.: Appl., Theory Instrum. 2009, 635-666. [CrossRef]

81. Rangachari, V.; Reed, D.K.; Moore, B.D.; Rosenberry, T.L. Secondary structure and interfacial aggregation of amyloid- $\beta(1-40)$ on sodium dodecyl sulfate micelles. Biochemistry 2006, 45, 8639-8648. [CrossRef] [PubMed]

82. Rangachari, V.; Moore, B.D.; Reed, D.K.; Sonoda, L.K.; Bridges, A.W.; Conboy, E.; Hartigan, D.; Rosenberry, T.L. Amyloid- $\beta(1-42)$ rapidly forms protofibrils and oligomers by distinct pathways in low concentrations of sodium dodecylsulfate. Biochemistry 2007, 46, 12451-12462. [CrossRef] [PubMed]

83. Irie, Y.; Murakami, K.; Hanaki, M.; Hanaki, Y.; Suzuki, T.; Monobe, Y.; Takai, T.; Akagi, K.I.; Kawase, T.; Hirose, K.; et al. Synthetic models of quasi-stable amyloid $\beta 40$ oligomers with significant neurotoxicity. ACS Chem. Neurosci. 2017, 8, 807-816. [CrossRef] [PubMed]

84. Yang, Y.W.; Tsai, C.W.; Mong, M.C.; Yin, M.C. Maslinic acid protected PC12 cells differentiated by nerve growth factor against $\beta$-amyloid-induced apoptosis. J. Agri. Food Chem. 2015, 63, 10243-10249. [CrossRef] [PubMed]

85. de la Torre, R.; Dierssen, M. Therapeutic approaches in the improvement of cognitive performance in Down syndrome: Past, present, and future. Prog. Brain Res. 2012, 197, 1-14. [PubMed]

86. Salloway, S.; Sperling, R.; Keren, R.; Porsteinsson, A.P.; van Dyck, C.H.; Tariot, P.N.; Gilman, S.; Arnold, D.; Abushakra, S.; Hernandez, C.; et al. A phase 2 randomized trial of ELND005, scyllo-inositol, in mild to moderate Alzheimer disease. Neurology 2011, 77, 1253-1262. [CrossRef]

87. Ringman, J.M.; Frautschy, S.A.; Teng, E.; Begum, A.N.; Bardens, J.; Beigi, M.; Gylys, K.H.; Badmaev, V.; Heath, D.D.; Apostolova, L.G.; et al. Oral curcumin for Alzheimer's disease: Tolerability and efficacy in a 24-week randomized, double blind, placebo-controlled study. Alzheimers Res. Ther. 2012, 4, 43. [CrossRef]

88. Nelson, K.M.; Dahlin, J.L.; Bisson, J.; Graham, J.; Pauli, G.F.; Walters, M.A. The essential medicinal chemistry of curcumin. J. Med. Chem. 2017, 60, 1620-1637. [CrossRef]

89. Chow, S.-C.; Chiu, S.-T. A note on design and analysis of clinical trials. Drug Des.: Open Access 2013, 2, 102. 
90. Chin, D.; Huebbe, P.; Pallauf, K.; Rimbach, G. Neuroprotective properties of curcumin in Alzheimer's disease-merits and limitations. Curr. Med. Chem. 2013, 20, 3955-3985. [CrossRef]

91. Minter, M.R.; Zhang, C.; Leone, V.; Ringus, D.L.; Zhang, X.; Oyler-Castrillo, P.; Musch, M.W.; Liao, F.; Ward, J.F.; Holtzman, D.M.; et al. Antibiotic-induced perturbations in gut microbial diversity influences neuro-inflammation and amyloidosis in a murine model of Alzheimer's disease. Sci. Rep. 2016, 6, 30028. [CrossRef] [PubMed]

92. Cummings, J.H.; Pomare, E.W.; Branch, W.J.; Naylor, C.P.; Macfarlane, G.T. Short chain fatty acids in human large intestine, portal, hepatic and venous blood. Gut 1987, 28, 1221-1227. [CrossRef] [PubMed]

93. Macfarlane, G.T.; Macfarlane, S. Bacteria, colonic fermentation, and gastrointestinal health. J. AOAC Int. 2012, 95, 50-60. [CrossRef] [PubMed]

94. Ho, L.; Ono, K.; Tsuji, M.; Mazzola, P.; Singh, R.; Pasinetti, G.M. Protective roles of intestinal microbiota derived short chain fatty acids in Alzheimer's disease-type $\beta$-amyloid neuropathological mechanisms. Exp. Rev. Neurother. 2018, 18, 83-90. [CrossRef] [PubMed]

95. Harach, T.; Marungruang, N.; Duthilleul, N.; Cheatham, V.; Mc Coy, K.D.; Frisoni, G.; Neher, J.J.; Fak, F.; Jucker, M.; Lasser, T.; et al. Reduction of A $\beta$ amyloid pathology in APPPS1 transgenic mice in the absence of gut microbiota. Sci. Rep. 2017, 7, 41802. [CrossRef] [PubMed]

96. Manach, C.; Donovan, J.L. Pharmacokinetics and metabolism of dietary flavonoids in humans. Free Radic. Res. 2004, 38, 771-785. [CrossRef] [PubMed]

97. Krizkova, J.; Burdova, K.; Stiborova, M.; Kren, V.; Hodek, P. The effects of selected flavonoids on cytochromes P450 in rat liver and small intestine. Interdiscip. Toxicol. 2009, 2, 201-204. [CrossRef] [PubMed]

98. Asakawa, T.; Hiza, A.; Nakayama, M.; Inai, M.; Oyama, D.; Koide, H.; Shimizu, K.; Wakimoto, T.; Harada, N.; Tsukada, H.; et al. PET imaging of nobiletin based on a practical total synthesis. Chem. Commun. 2011, 47, 2868-2870. [CrossRef] [PubMed]

99. Cote, C.D.; Rasmussen, B.A.; Duca, F.A.; Zadeh-Tahmasebi, M.; Baur, J.A.; Daljeet, M.; Breen, D.M.; Filippi, B.M.; Lam, T.K. Resveratrol activates duodenal Sirt1 to reverse insulin resistance in rats through a neuronal network. Nat. Med. 2015, 21, 498-505. [CrossRef] [PubMed]

100. Duca, F.A.; Cote, C.D.; Rasmussen, B.A.; Zadeh-Tahmasebi, M.; Rutter, G.A.; Filippi, B.M.; Lam, T.K. Metformin activates a duodenal Ampk-dependent pathway to lower hepatic glucose production in rats. Nat. Med. 2015, 21, 506-511. [CrossRef] [PubMed]

101. Jaunmuktane, Z.; Mead, S.; Ellis, M.; Wadsworth, J.D.; Nicoll, A.J.; Kenny, J.; Launchbury, F.; Linehan, J.; Richard-Loendt, A.; Walker, A.S.; et al. Evidence for human transmission of amyloid- $\beta$ pathology and cerebral amyloid angiopathy. Nature 2015, 525, 247-250. [CrossRef] [PubMed] 